\title{
CORRELATION BETWEEN INDICATORS OF HYPOVOLEMIA AND RESPONSE TO INFUSION THERAPY IN FLUID RESUSCITATION OF PATIENTS WITH SEPTIC SHOCK
}

\section{KORELACJA POMIĘDZY WSKAŹNIKAMI HIPOWOLEMII I REAKCJĄ NA TERAPIĘ INFUZYJNĄ W UZUPEŁNIANIU PŁYNÓW U PACJENTÓW ZE WSTRZĄSEM SEPTYCZNYM}

\author{
Tinglan Zuo $^{1(\mathrm{~A}, \mathrm{~B}, \mathrm{C}, \mathrm{D}, \mathrm{E}, \mathrm{F})}$, Felix Semenovich Glumcher $^{(\mathrm{A}, \mathrm{D}, \mathrm{E})}$, Evgeny Yurievich Demin ${ }^{1(\mathrm{D}, \mathrm{E})}$ \\ ${ }^{1}$ Department of Anesthesiology and Intensive Care, Bohomolets National Medical University, Kyiv, Ukraine
}

Authors' contribution Wkład autorów: A. Study design/planning zaplanowanie badań B. Data collection/entry zebranie danych C. Data analysis/statistics dane - analiza i statystyki D. Data interpretation interpretacja danych E. Preparation of manuscript przygotowanie artykułu F. Literature analysis/search wyszukiwanie i analiza literatury G. Funds collection zebranie funduszy

\section{Summary}

Background. Infusion therapy is the primary stage of resuscitation in patients with septic shock. But excess fluids may cause adverse outcomes, so which indicators should doctors monitor to predict whether the infusion volume is sufficient?

Material and methods. The prospective clinical study included 68 consecutive intensive care unit (ICU) adult patients with septic shock, who had an active surgical infection. Minimally invasive methods were used to continuously record cardiac output (CO). In this study, we compare the passive leg raise (PLR) test and initial central venous oxygen saturation $\left(\mathrm{ScvO}_{2}\right)$ levels in terms of correlation with, and predictive accuracy for, infusion response.

Results. The predictive accuracy of PLR testing and initial $\mathrm{ScvO}_{2}$ levels for infusion response was $55.9 \%$ vs. $67.6 \%$ in septic shock patients with abdominal infection. Results from the PLR test and reaction to infusion therapy revealed a slight positive correlation $(\mathrm{R}=0.239, \mathrm{P}=0.018)$, initial $\mathrm{ScvO}_{2}$ and reaction to infusion therapy revealed a moderate negative correlation $(\mathrm{R}=-0.305, \mathrm{P}=0.009)$.

Conclusions. In intra-abdominal septic shock patients, the PLR test is not a reliable predictor of response to infusion, but low initial $\mathrm{ScvO}_{2}$ levels can be used for the prediction of response to infusion. Administering a fluid challenge with dynamic indicators (such as $\mathrm{CO}$ ) is the most accurate method for clinicians to determine the need for further infusion therapy.

Keywords: septic shock, fluid therapy, intra-abdominal infections, cardiac output, intraabdominal hypertension

\section{Streszczenie}

Wprowadzenie. Terapia infuzyjna jest pierwszym etapem uzupełniania płynów u pacjentów ze wstrzasem septycznym. Nadmiar płynów powoduje jednak przeciwne skutki. Jakie wskaźniki powinni zatem kontrolować lekarze, aby przewidzieć, czy objętość infuzji jest wystarczająca? Materiał i metody. W klinicznym badaniu prospektywnym wzięło udział 68 pacjentów oddziału intensywnej opieki medycznej (OIOM) ze wstrząsem septycznym i aktywnym zakażeniem chirurgicznym. Do stałego zapisywania rzutu serca (CO, ang. cardiac output) zastosowano metody minimalnie inwazyjne. Porównano wyniki testu biernego uniesienia kończyn dolnych (PLR, ang. passive leg raise) z wyjściowym poziomem saturacji krwi żylnej z żyły głównej górnej $\left(\mathrm{ScvO}_{2}\right.$, ang. central venous oxygen saturation) z dokładnością predykcyjną w reakcji na infuzje i korelacje z nią.

Wyniki. Dokładność predykcyjna testu PLR i wyjściowego poziomu $\mathrm{ScvO}_{2}$ w reakcji na infuzję wyniosła 55,9\% w porównaniu z 67,6\% u pacjentów ze wstrząsem septycznym i infekcją brzuszna. Test PRL i reakcja na terapię infuzyjna wykazały niewielką korelacje pozytywną $(\mathrm{R}=0,239, \mathrm{P}=0,018)$, natomiast wyjściowy poziom $\mathrm{ScvO}_{2}$ i reakcja na terapię infuzyjną wskazały na umiarkowaną korelację negatywną $(\mathrm{R}=-0,305, \mathrm{P}=0,009)$.

Wnioski. U pacjentów ze wstrząsem septycznym w obrębie jamy brzusznej test PLR nie jest wiarygodnym czynnikiem prognostycznym reakcji na infuzję, jednak niski wyjściowy poziom $\mathrm{ScvO}_{2}$ może zostać wykorzystany do jej prognozy. Nawadnianie ze wskaźnikami dynamicznymi (np. CO) jest najdokładniejszą metodą określania dalszego zapotrzebowania na terapię infuzyjną stosowaną przez klinicystów.

Słowa kluczowe: wstrząs septyczny, płynoterapia, infekcje jamy brzusznej, rzut serca, nadciśnienie śródbrzuszne

\section{Tables: 4}

References: 23

Submitted: 2020 Sep 2

Accepted: 2021 Jan 11

Zuo T, Glumcher FS, Demin EY. Correlation between indicators of hypovolemia and response to infusion therapy in fluid resuscitation of patients with septic shock. Health Prob Civil. 2021; 15(1): 54-60. https://doi.org/10.5114/hpc.2021.102569

Address for correspondence / Adres korespondencyjny: Tinglan Zuo, Department of Anesthesiology and Intensive Care, Bohomolets National Medical University, Solomianska Street 17, 03110 Kyiv, Ukraine, e-mail: zuotinglan@hotmail.com, phone: +380 93056 9388, ORCID: Tinglan Zuo https://orcid.org/0000-0003-1080-0290 Copyright: (C) Pope John Paul II State School of Higher Education in Biała Podlaska, Tinglan Zuo, Felix Semenovich Glumcher, Evgeny Yurievich Demin. This is an Open Access journal, all articles are distributed under the terms of the Creative Commons Attribution-NonCommercial-ShareAlike 4.0 International (CC BY-NC-SA 4.0) License (http://creativecommons.org/licenses/by-nc-sa/4.0/), allowing third parties to copy and redistribute the material in any medium or format and to remix, transform, and build upon the material, provided the original work is properly cited and states its license. 


\section{Introduction}

Infusion therapy is a key component of septic shock treatment [1]. Timely infusion therapy is crucial for cardiac output (CO) improvement, restoration of oxygen delivery, and prevention of multiple organ dysfunction syndrome (MODS) in septic shock [1]. Therefore, infusion therapy is recommended as a first-line intervention for the resuscitation of patients with this pathology [2]. Timely fluid resuscitation is associated with a reduction in in-hospital mortality [3], while a delay in resuscitation is associated with the release of inflammatory mediators, mitochondrial dysfunction, and a poorer prognosis [4].

The large volumes of transfused fluid often required in the treatment of septic shock can lead to hypervolemia, which is no less dangerous than hypovolemia [5]. Also, the recommendations of the Surviving Sepsis Campaign 2016 [6] indicate that after the initial infusion of crystalline solutions at a dose of $30 \mathrm{~mL} / \mathrm{kg}$, further liquid demand should be determined individually based on dynamic indicators, but which indicators should be given priority are not specified. Data from existing literature favors dynamic indicators e.g. CO and cardiac index (CI) over static indicators ( $\mathrm{ScvO}_{2}, \mathrm{CVP}$, lactate level) [7].

According to modern concepts, the pace of infusion therapy must be corrected depending on the body's response to the fluid introduction; if the $\mathrm{CO}$ increases in response to infusion, the transfusion of fluid should be continued. If $\mathrm{CO}$ does not increase, the pace of infusion should be decreased along with the use of vasopressors and cardiotonics. It is considered that a passive leg raising test (PLR test), which induces 150-300 mL of blood to flow back from the venous circulation of the lower body to the chest (self-volume challenge), is useful for assessing the body's response to a fluid transfusion.

Central venous blood saturation $\left(\mathrm{ScvO}_{2}\right)$ is one of the parameters for determining the global adequacy of oxygen transport and oxygen demand, and the most common reason for decreased $\mathrm{ScvO}_{2}$ in patients with septic shock is global organ perfusion disorder due to decreased CO caused by hypovolemia.

The objective of this study was to determine the correlation between different indicators of hypovolemia and the reaction to infusion therapy in fluid resuscitation of patients with septic shock. Since the "fluid challenge" presents a risk of developing hypervolemia, we aim to explore which parameters can most accurately predict response to fluid challenge thereby reducing the risk of hypervolemia in patients with septic shock.

\section{Material and methods}

A prospective clinical study was carried out in the Department of Anesthesiology and Intensive Care of Kyiv City Clinical Hospital No. 4, Ukraine. Permission to conduct the research was received from the Ethics Committee of Kyiv City Clinical Hospital No. 4.

The study involved patients over 18 years old, who were hospitalized in ICU, had an active surgical infection (intestinal obstruction, hollow organ perforation, infected pancreatitis, abscess of the parenchymatous organs, peritonitis of other origins), and were in a state of septic shock following surgical intervention. Septic shock was defined according to the criteria of The Third International Consensus Definitions for Sepsis and Septic Shock (Sepsis-3) [8], as sepsis (an increase of SOFA score of 2 or more points) with plasma lactate level above $2 \mathrm{mmol} \backslash \mathrm{L}$ and the need for vasopressors to maintain mean arterial pressure (MAP) at a level $\geq 65 \mathrm{mmHg}$.

The study did not include patients whose condition was considered non-curable (terminal stage of cancer, total mesenteric thrombosis), or those who at the time of screening had already received a significant amount of infusion therapy $(>1,000 \mathrm{ml})$ within the last 3 hours.

After screening of patients, but before the beginning of infusion, basic parameters of hemodynamics, plasma lactate level and parameters of general and biochemical blood tests were measured according to local standards of treatment of patients of Kyiv City Clinical Hospital No. 4. Hemodynamic parameters such as CO, CI, stroke volume (SV) and stroke volume index (SVI) were monitored using an esophageal Doppler transducer and associated monitor (CardioQ ODM+, Model No. 9051-6935, Deltex Medical, UK) and pulse-wave velocity analysis (bedside monitor with continuous CO measurement by esCCO ${ }^{\mathrm{TM}}$ method, model: BSM-3562, Nihon Kohden, Japan). The lactate content was determined using a photometric express system (Accutrend Plus, Roche, Germany). Noninvasive blood pressure, pulse oximetry, heart rate, ECG, $\mathrm{ScvO}_{2}$, central venous pressure (CVP), and vasopressor demand were also monitored.

The PLR test was performed before infusion by raising the lower limbs to a $45^{\circ}$ angle while the patient's trunk was lowered, as previously reported by Monnet et al. [9]. If the CO increased by $\geq 10 \%$ after lifting the lower limbs, the PLR test was considered positive.

An isotonic crystalloid solution with a volume of $500 \mathrm{~mL}$ was used for resuscitation. The internal jugular vein was catheterized in all patients and the solution was injected through the central venous catheter (certofix duo 720, B. Braun, Germany), catheter diameter G16, injection speed 27-33 mL/min. We recorded the CO before and 
after infusion. If $\mathrm{CO}$ increased by $\geq 10 \%$ following infusion, the reaction to the infusion was considered positive. Vasopressor doses and mechanical ventilation (MV) parameters did not change during the study.

Statistical processing was performed in SPSS Statistics 25.0.0 software (IBM Corporation, 2018). KolmogorovSmirnov and Shapiro-Wilk criteria were used to check the distribution normality. Depending on the type of data distribution, methods of parametric (Student's criterion) and non-parametric (chi-square criterion, MannWhitney U-test) statistics were used. Correlation was calculated using Pearson correlation coefficient. In the results, the data with parametric distributions are presented as arithmetic mean (M) \pm standard deviation (SD). When submitting graphical information, the standard error (SE) is displayed. For some indicators -95\% and $+95 \%$ confidence intervals (CI) are specified. Non-parametric internal data are presented as median (lower quartile; upper quartile). The rule of arithmetic rounding was used to present all results of statistical processing with an accuracy of corresponding experimental indicators. The difference was considered statistically significant when the probability of a false refutation of the null hypothesis was less than $5 \%(\mathrm{P}<0.05)$.

\section{Results}

The characteristics of 68 patients, included in the study, are presented in Table 1.

Table 1. Patient characteristics $(\mathrm{n}=68)$

\begin{tabular}{|c|c|c|}
\hline Age (years) & Arithmetic mean (M) \pm standard deviation (SD) & $66.64 \pm 16.73$ \\
\hline \multirow{2}{*}{ Sex } & Male & $28(41.2 \%)$ \\
\hline & Female & $40(58.8 \%)$ \\
\hline Weight (kg) & $\begin{array}{c}\text { Median } \\
\text { (lower quartile; upper quartile) }\end{array}$ & $\begin{array}{c}67 \\
(60 ; 80) \\
\end{array}$ \\
\hline Height (cm) & Arithmetic mean $(\mathrm{M}) \pm$ standard deviation (SD) & $167.52 \pm 8.88$ \\
\hline BMI $\left(\mathrm{kg} / \mathrm{m}^{2}\right)$ & $\begin{array}{c}\text { Median } \\
\text { (lower quartile; upper quartile) }\end{array}$ & $\begin{array}{c}24.17 \\
(22.20 ; 27.08) \\
\end{array}$ \\
\hline BSA $\left(\mathrm{m}^{2}\right)$ & $\begin{array}{c}\text { Median } \\
\text { (lower quartile; upper quartile) }\end{array}$ & $\begin{array}{c}1.78 \\
(1.64 ; 1.92) \\
\end{array}$ \\
\hline APACHE II score, points & Arithmetic mean $(\mathrm{M}) \pm$ standard deviation (SD) & $15.71 \pm 1.80$ \\
\hline Initial SOFA score, points & Arithmetic mean (M) \pm standard deviation (SD) & $8.33 \pm 3.45$ \\
\hline $\begin{array}{c}\text { Initial lactate level, } \\
\mathrm{mmol} / \mathrm{L}\end{array}$ & $\begin{array}{c}\text { Median } \\
\text { (lower quartile; upper quartile) }\end{array}$ & $\begin{array}{c}4.1 \\
(3.15 ; 6.35)\end{array}$ \\
\hline Initial MAP, mmHg. & $\begin{array}{l}\text { Arithmetic mean (M) } \pm \text { standard deviation (SD) } \\
(95 \% \mathrm{CI})\end{array}$ & $\begin{array}{c}66.29 \pm 8.81 \\
(63.73-68.85)\end{array}$ \\
\hline $\begin{array}{c}\text { Noradrenaline } \\
\text { administration rate }(\mu \mathrm{g} / \\
\mathrm{kg} / \mathrm{min})\end{array}$ & $\begin{array}{c}\text { Median } \\
\text { (lower quartile; upper quartile) }\end{array}$ & $\begin{array}{c}0.16 \\
(0.04 ; 0.39)\end{array}$ \\
\hline
\end{tabular}

Table 2 shows the distribution of patients according to the location of surgical infection.

Table 2. Patient distribution by source of surgical infection

\begin{tabular}{|c|c|c|}
\hline Source of surgical infection & Number of patients & Percentage \\
\hline Intestinal obstruction & 27 & $39.7 \%$ \\
\hline Hollow organ perforation & 22 & $10.3 \%$ \\
\hline Infected pancreatitis & 7 & $7.4 \%$ \\
\hline Partial mesenteric thrombosis & 5 & $4.4 \%$ \\
\hline Abscess of the parenchymatous organs & 3 & $5.9 \%$ \\
\hline Peritonitis of other origins & 4 & $100 \%$ \\
\hline Total & 68 & \\
\hline
\end{tabular}

The results of PLR testing are presented in Table 3, sensitivity (ability to detect positive reaction to infusion) $=53.8 \%$ with $100 \%$ correctness; specificity (ability to detect negative reaction to infusion) $=100 \%$ with a correctness of $9 \%$; test accuracy $=55.9 \%$. 
Table 3. Organization of data to evaluate PLR test informativeness

\begin{tabular}{|c|c|c|c|}
\hline \multirow{2}{*}{ PLR-test } & \multicolumn{2}{|c|}{ Infusion response according to C0 } & \multirow{2}{*}{ Total } \\
\cline { 2 - 4 } & Positive & Negative & $35(51.5 \%)$ \\
\hline Positive & 35 & 0 & $33(48.5 \%)$ \\
\hline Negative & 30 & 3 & $68(100 \%)$ \\
\hline Total & $65(95.6 \%)$ & $3(4.4 \%)$ & \\
\hline
\end{tabular}

Notes: In the septic shock patients with abdominal infection, $51.5 \%$ were true positive PLR-test results, $0 \%$ were false positive PLR-test results, $44.1 \%$ were false negative PLR-test results, and $4.4 \%$ were true negative PLR-test results. Test sensitivity $=53.8 \%$, test specificity $=100 \%$.

Almost half of the patients had negative PLR test results, however, taking into account other clinical and laboratory parameters, including $\mathrm{ScvO}_{2}$, the decision was made to perform a test with $500 \mathrm{~mL}$ isotonic crystalloid solution infusion (fluid challenge). Then, the correlation relations of the two methods and the reaction to fluid infusion were determined.

The relationship of $\mathrm{ScvO}_{2}$ and the response to infusion are presented in Table 4, sensitivity (ability to detect positive reaction to infusion) $=70.8 \%$ with $100 \%$ correctness; specificity (ability to detect negative reaction to infusion) $=100 \%$ with a correctness of $13.6 \%$; test accuracy $=67.6 \%$.

Table 4. Evaluation of $\mathrm{ScvO}_{2}$ as a predictor of response to infusion (fluid challenge)

\begin{tabular}{|c|c|c|c|}
\hline & \multicolumn{2}{|c|}{ Infusion response according to CO } & \multirow{2}{*}{ Total } \\
\cline { 2 - 4 } & Positive & Negative & $46(67.6 \%)$ \\
\hline $\mathbf{S c v O}_{2}<\mathbf{7 0} \%$ & 46 & 0 & $22(32.4 \%)$ \\
\hline $\mathbf{S c v O}_{2} \geq \mathbf{7 0} \%$ & 19 & 3 & $68(100 \%)$ \\
\hline Total & $65(95.6 \%)$ & $3(4.4 \%)$ & \\
\hline
\end{tabular}

Notes: The predictive results of initial $\mathrm{ScvO}_{2}$ levels for infusion response in septic shock patients with abdominal infection, $67.6 \%$ were true positives, $0 \%$ were false positives, $27.9 \%$ were false negatives, and $4.4 \%$ were true negatives. Sensitivity $=70.8 \%$, specificity $=100 \%$.

At the stage of fluid resuscitation of patients with septic shock, PLR-test and reaction to infusion therapy revealed a slight positive correlation $\left(\mathrm{R}=0.239, \mathrm{P}=0.018\right.$ ) (Figure 1), initial $\mathrm{ScvO}_{2}$ and reaction to infusion therapy revealed a moderate negative correlation $(\mathrm{R}=-0.305, \mathrm{P}=0.009)$ (Figure 2). The Chaddock scale was used to estimate the strength of the correlation relation.

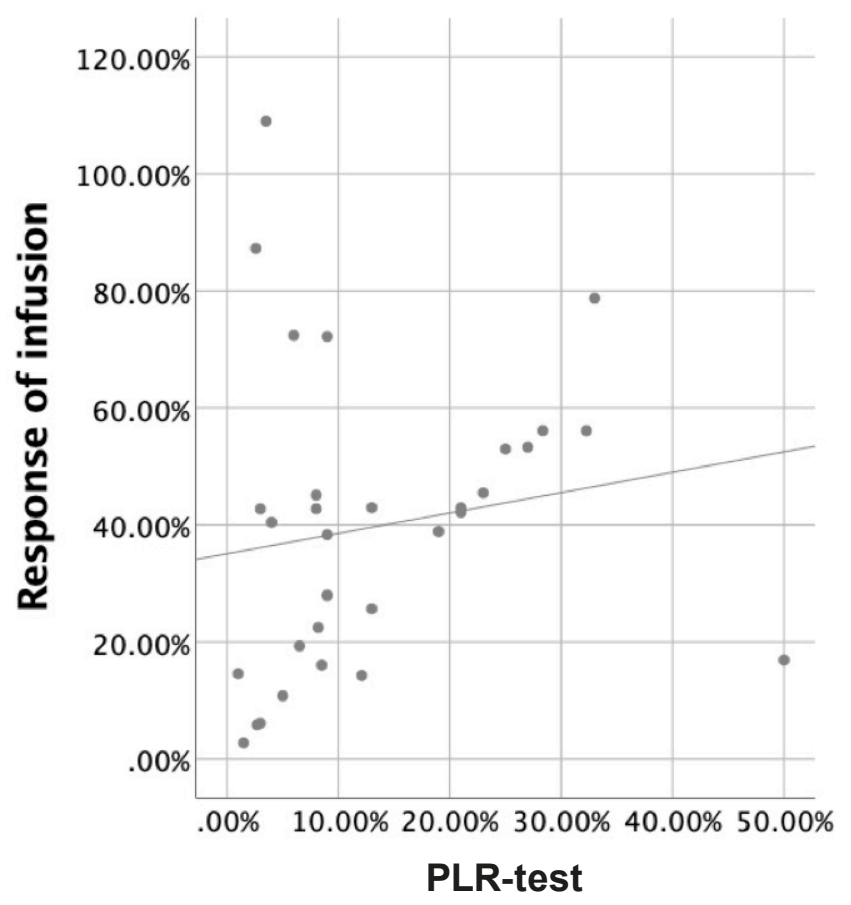

Figure 1. Correlation of the PLR test and reaction to infusion therapy 


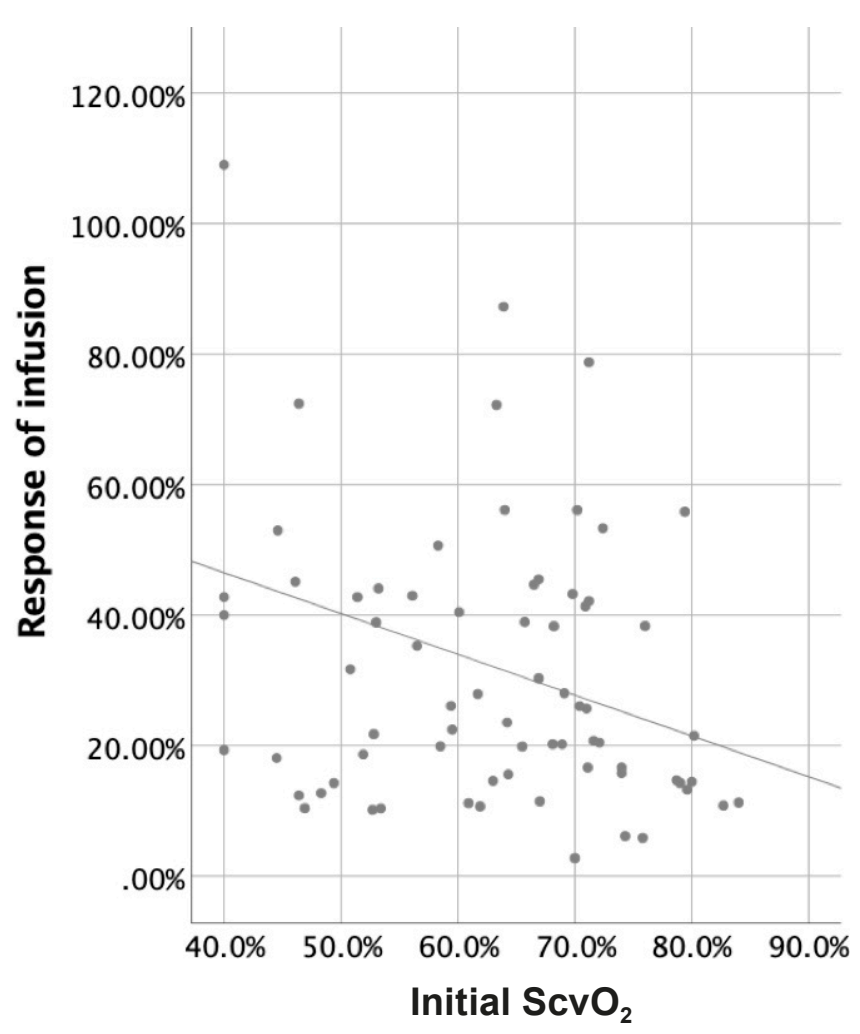

Figure 2. Correlation of initial $\mathrm{ScvO}_{2}$ and reaction to infusion therapy

Among the patient group studied, 39.7\% were diagnosed with intestinal obstruction, 32.4\% were diagnosed with perforation of luminal organs, and $10.3 \%$ were diagnosed with infected pancreatitis. We divided the patients with these three diagnoses into three subgroups and found that there was a strong positive correlation between PRL-test and infusion response in the intestinal obstruction subgroup ( $R=0.67, P=0.012)$. However, there was no such correlation found in patients with luminal organ perforation or infected pancreatitis $(\mathrm{P}=0.192$ and 0.426 respectively).

\section{Discussion}

In the course of conducting this research, contradictory data that conflicts with existing researches was obtained [10-15]. In particular, the passive leg raising test (PLR-test) showed low sensitivity to positive infusion, and most patients with a negative PLR-test had a positive infusion response anyway. Among the possible causes may be the abdominal genesis of sepsis in patients of the research, because current literature data shows the ineffectiveness of the PLR test in patients with intra-abdominal hypertension (IAH) [16,17], and abdominal surgery is a risk factor for the development of intra-abdominal hypertension and abdominal compartment syndrome [18].

Nasogastric drainage tubes were inserted into all patients during their surgical procedure. In principle, they help to maintain a relatively normal intra-abdominal pressure (IAP) level, however the intra-abdominal pressure was not measured routinely in patients in the study, which is a limitation of our study. The influence of IAP on hemodynamics is complex. The direct effect of IAP on the extrathoracic veins leads to an increase in venous return pressure, but a significant increase of right atrial pressure causes venous return and CO to decrease. When the IAP increases from 0 to $30 \mathrm{mmHg}$, SV and CO decrease. The increase of IAP increases the left ventricular (LV) afterload by increasing the resistance of the extrathoracic arteries, and is accompanied by an increase in right atrial pressure and right ventricular afterload, which may cause a decrease in CO. In this study, we were more concerned about the effect of IAP on dynamic parameters. In fact, in the study of A. Beurton et al. [19], the PLR test decreases IAP in patients with IAH as well as in patients without it. IAH decreases the amplitude of the PLR-induced increase in $\mathrm{CO}$ in fluid responders. It is responsible for some of the false negatives which occurred when testing the PLR test as a predictor of fluid responsiveness.

Also, a strong predictor of the response to infusion therapy was low initial $\mathrm{ScvO}_{2}$, despite the existing published data on the low diagnostic value of this indicator. The working hypothesis of the research group is 
that the most accurate method of determining fluid requirement is a direct measurement of the response to the test dose of fluid (fluid challenge), followed by the accuracy of the PRL-test, but the final results are somewhat different. The incidence of IAH in patients with severe acute pancreatitis is high $60-80 \%$ depending on the population considered) [20]. The septic shock caused by the perforation of hollow organs is associated with IAH occurring in $62 \%$ [21]. Due to the increase of intestinal contents [22], intestinal obstruction is also a risk factor for IAH. But most studies of intra-abdominal pressure in patients with intestinal obstruction were carried out before operational intervention. In fact, the problem of obstruction was solved during operation, and most of the intra-luminal contents were evacuated, so the postoperative intra-abdominal pressure was significantly reduced [23]. This may explain why there is a weak positive correlation between PRL-test and infusion response in these patients with a strong positive correlation found in the intestinal obstruction subgroup, but no similar correlation found in the hollow organ perforation subgroup and infected pancreatitis subgroup.

Doctors sometimes ignore IAH when there is a decompression system and a "soft abdomen". When deciding to provide infusion therapy to patients with abdominal septic shock, different parameters need to be monitored, and it is important to compare benefits and risks individually. For patients with the risk of IAH, IAP should be measured before PRL-testing. Routine measurement of IAP is necessary for septic shock patients who have undergone abdominal surgery.

\section{Conclusions}

1. The results show that the PLR test is not a reliable predictor of the response to infusion in patients with intra-abdominal septic shock.

2. A low initial $\mathrm{ScvO}_{2}$ is an indication for assessing the response to infusion in patients with septic shock.

3. The direct measurement of the response to the infusion (fluid challenge) is the most accurate method of determining the need for further infusion therapy.

4. The data confirm that almost all patients have initial hypovolemia and a positive reaction to the infusion. After the initial infusion, an assessment using dynamic indicators is necessary to determine the further need for infusion therapy.

\section{Disclosures and acknowledgements}

This study is a part of the research topic of the Department of Anesthesiology and Intensive Care of the NMU named after 0.0. Bohomolets: "Optimization of methods of anesthetic management and intensive care in patients of different age groups" (registration number 0112U001413). The authors are the executors of the mentioned topic fragment.

\section{References:}

1. Angus DC, van der Poll T. Severe sepsis and septic shock. N Engl J Med. 2013; 369(21): 2063. https://doi.org/10.1056/NEJMra1208623

2. Dellinger RP, Levy MM, Rhodes A, Annane D, Gerlach H, Opal SM, et al. Surviving Sepsis Campaign: international guidelines for management of severe sepsis and septic shock, 2012. Intensive Care Med. 2013; 39(2): 165-228. https://doi.org/10.1007/s00134-012-2769-8

3. Lee SJ, Ramar K, Park JG, Gajic 0, Li G, Kashyap R. Increased fluid administration in the first three hours of sepsis resuscitation is associated with reduced mortality: a retrospective cohort study. Chest. 2014; 146(4): 908-915. https://doi.org/10.1378/chest.13-2702

4. Correa TD, Vuda M, Blaser AR, Takala J, Djafarzadeh S, Dunser MW, et al. Effect of treatment delay on disease severity and need for resuscitation in porcine fecal peritonitis. Crit Care Med. 2012; 40(10): $2841-2849$. https://doi.org/10.1097/CCM.0b013e31825b916b

5. Vaara ST, Korhonen AM, Kaukonen KM, Nisula S, Inkinen O, Hoppu S, et al. Fluid overload is associated with an increased risk for 90-day mortality in critically ill patients with renal replacement therapy: data from the prospective FINNAKI study. Crit Care. 2012; 16(5): R197. https://doi.org/10.1186/cc11682

6. Rhodes A, Evans LE, Alhazzani W, Levy MM, Antonelli M, Ferrer R, et al. Surviving Sepsis Campaign: International Guidelines for Management of Sepsis and Septic Shock: 2016. Intensive Care Med. 2017; 43(3): 304-377. https://doi.org/10.1007/s00134-017-4683-6

7. Monnet X, Marik PE, Teboul JL. Prediction of fluid responsiveness: an update. Ann Intensive Care. 2016; 6(1): 111. https://doi.org/10.1186/s13613-016-0216-7 
8. Singer M, Deutschman CS, Seymour CW, Shankar-Hari M, Annane D, Bauer M, et al. The third international consensus definitions for sepsis and septic shock (Sepsis-3). JAMA. 2016; 315(8): 801-810. https://doi.org/10.1001/jama.2016.0287

9. Monnet X, Teboul JL. Passive leg raising: five rules, not a drop of fluid!. Crit Care. 2015; 1918. https://doi.org/10.1186/s13054-014-0708-5

10. Cavallaro F, Sandroni C, Marano C, La Torre G, Mannocci A, De Waure C, et al. Diagnostic accuracy of passive leg raising for prediction of fluid responsiveness in adults: systematic review and meta-analysis of clinical studies. Intensive Care Med. 2010; 36(9): 1475-1483. https://doi.org/10.1007/s00134-010-1929-y

11. Lakhal K, Ehrmann S, Benzekri-Lefevre D, Runge I, Legras A, Dequin PF, et al. Brachial cuff measurements of blood pressure during passive leg raising for fluid responsiveness prediction. Ann Fr Anesth Reanim. 2012; 31(5): e67-72. https://doi.org/10.1016/j.annfar.2012.01.032

12. Lakhal K, Ehrmann S, Runge I, Benzekri-Lefevre D, Legras A, Dequin PF, et al. Central venous pressure measurements improve the accuracy of leg raising-induced change in pulse pressure to predict fluid responsiveness. Intensive Care Med. 2010; 36(6): 940-948. https://doi.org/10.1007/s00134-010-1755-2

13. Monnet X, Bleibtreu A, Ferre A, Dres M, Gharbi R, Richard C, et al. Passive leg-raising and end-expiratory occlusion tests perform better than pulse pressure variation in patients with low respiratory system compliance. Crit Care Med. 2012; 40(1): 152-157. https://doi.org/10.1097/CCM.0b013e31822f08d7

14. Benomar B, Ouattara A, Estagnasie P, Brusset A, Squara P. Fluid responsiveness predicted by noninvasive bioreactance-based passive leg raise test. Intensive Care Med. 2010; 36(11): 1875-1881.

https://doi.org/10.1007/s00134-010-1990-6

15. Biais M, Vidil L, Sarrabay P, Cottenceau V, Revel P, Sztark F. Changes in stroke volume induced by passive leg raising in spontaneously breathing patients: comparison between echocardiography and Vigileo/FloTrac device. Crit Care. 2009; 13(6): R195. https://doi.org/10.1186/cc8195

16. Mahjoub Y, Touzeau J, Airapetian N, Lorne E, Hijazi M, Zogheib E, et al. The passive leg-raising maneuver cannot accurately predict fluid responsiveness in patients with intra-abdominal hypertension. Crit Care Med. 2010; 38(9): 1824-1829. https://doi.org/10.1097/CCM.0b013e3181eb3c21

17. Malbrain ML, Reuter DA. Assessing fluid responsiveness with the passive leg raising maneuver in patients with increased intra-abdominal pressure: be aware that not all blood returns!. Crit Care Med. 2010; 38(9): 1912-1915. https://doi.org/10.1097/CCM.0b013e3181f1b6a2

18. Rajasurya V, Surani S. Abdominal compartment syndrome: often overlooked conditions in medical intensive care units. World J Gastroenterol. 2020; 26(3): 266-278. https://doi.org/10.3748/wjg.v26.i3.266

19. Beurton A, Teboul JL, Girotto V, Galarza L, Anguel N, Richard C, et al. Intra-abdominal hypertension is responsible for false negatives to the passive leg raising test. Crit Care Med. 2019; 47(8): e639-e647. https://doi.org/10.1097/CCM.0000000000003808

20. Al-Bahrani AZ, Abid GH, Holt A, McCloy RF, Benson J, Eddleston J, et al. Clinical relevance of intra-abdominal hypertension in patients with severe acute pancreatitis. Pancreas. 2008; 36(1): 39-43. https://doi.org/10.1097/mpa.0b013e318149f5bf

21. Basu A, Pai DR. Early elevation of intra-abdominal pressure after laparotomy for secondary peritonitis: a predictor of relaparotomy?. World J Surg. 2008; 32(8): 1851-1856. https://doi.org/10.1007/s00268-008-9605-x

22. Kirkpatrick AW, Roberts DJ, De Waele J, Jaeschke R, Malbrain ML, De Keulenaer B, et al. Intra-abdominal hypertension and the abdominal compartment syndrome: updated consensus definitions and clinical practice guidelines from the World Society of the Abdominal Compartment Syndrome. Intensive Care Med. 2013; 39(7): 1190-1206. https://doi.org/10.1007/s00134-013-2906-z

23. Glushkov NI, Pakhmutova YA, Belsky II, Safin MG, Shchur MS. [The role of abdominal hypertension in optimizing the treatment of patients with acute intestinal obstruction]. HERALD of North-Western State Medical University named after II Mechnikov. 2018; 10(1): 33-36 (in Russian).

https://doi.org/10.17816/mechnikov201810133-36 